\title{
Status of two nematode type species from the Bacteriological Institute of São Paulo included in the Helminthological Collection of the Oswaldo Cruz Institute (CHIOC)
}

\author{
Dely Noronha ${ }^{1,2} \&$ Roberto M. Pinto ${ }^{1,3}$ \\ ${ }^{1}$ Laboratório de Helmintos Parasitos de Vertebrados, Departamento de Helmintologia, Instituto Oswaldo Cruz. Avenida \\ Brasil 4365, Manguinhos, 21040-900 Rio de Janeiro, Rio de Janeiro, Brasil. \\ ${ }^{2}$ Curator of the CHIOC. Corresponding author. E-mail: dnoronha@ioc.fiocruz.br \\ ${ }^{3} \mathrm{CNPq}$ research fellow.
}

\begin{abstract}
The present deposit status of two nematode type species, Cruzia tentaculata (Rudolphi, 1819) and Katlania leptura (Rudolphi, 1819), now included in the Helminthological Collection of the Oswaldo Cruz Institute is informed.

KEY WORDS. Brazil; Cruzia tentaculata; Katlania leptura.

RESUMO. Situação de duas espécies-tipo de nematóides do Instituto Bacteriológico de São Paulo, incluídas na Coleção Helmintológica do Instituto Oswaldo Cruz. A atual situação de depósito de duas espécies-tipo de nematóides, Cruzia tentaculata (Rudolphi, 1819) e Katlania leptura (Rudolphi, 1819), agora incluídas na Coleção Helmintológica do Instituto Oswaldo Cruz, é informada.

PALAVRAS-CHAVE. Brasil; Cruzia tentaculata; Katlania leptura.
\end{abstract}

\begin{abstract}
Taking into account that the CHIOC has recently been declared one of the Brazilian holders of the genetic patrimony on behalf of the present curatorship, updating of data related to the deposited type species is under development. Among the helminth samples formerly maintained in the Bacteriological Institute of São Paulo and presently included in the Helminthological Collection of the Oswaldo Cruz Institute (CHIOC), Rio de Janeiro, two nematode type species were overlooked by ReGo et al. (1979) in the survey of types preserved in the CHIOC. Thus, Cruzia tentaculata (Rudolphi, 1819) Travassos, 1917 and Katlania leptura (Rudolphi, 1819) Travassos, 1918, are considered here. In relation to C. tentaculata, the type was proposed on the basis of the specimens preserved as wet material CHIOC no. 1413. Thus, the several specimens (40 males, 51 females) of the sample are regarded as syntypes taking into account that Travassos (1917) did not designate either the holotype or the paratypes. Although the inclusion occurred in 1917, the material was illustrated later (Travassos 1922), at the time that the description was enlarged. Nevertheless, the date of the nomination of the species has been misunderstood, since there are a large amount of references related to 1922, instead of 1917, when the new combination for the specific name was, in fact, proposed. The type host for this species is Didelphis aurita Wied-Neuwied, 1826, commonly named opossum. On
\end{abstract}

what refers to K. leptura, it was referred by Travassos (1917) as Pseudoheterakis lepturis (Schneider, 1866) and allocated in Pseudoheterakidae Travassos, 1917, presently invalidate, since later, Travassos (1918) considered P. lepturis a synonym of the type species of Katlania Lane, 1914, for which Katlaniidae Travassos, 1918, was proposed; this family, formerly allocated in Oxyuroidea is now included in Cosmocercoidea. When the specimens were included (Travassos 1917), the file numbers referred to CHIOC no.1411 (wet material) and 1412 (whole mount). In the opportunity, a correction is made: whole mounts are, in fact, composed of five slides, 1412 a-e ( 1 female, 1 unidentified fragment, 1 male, 1 female, 1 male, respectively) and the material previously preserved as wet material is now kept as whole mounts no. 1518 ( 1 male) and 1519 (1 male). Illustrations of K. leptura presented by Travassos (1918) were obtained on the basis of these whole mounts. The host for this species is Chelonia mydas (Linnaeus, 1758) (= Testudo mydas, Chelone mydas), commonly named turtle or sea turtle.

\section{REFERENCES}

Rego, A.A.; J.J. Vicente \& D.C. Gomes. 1979. List of holotypes in the Helminthological Collection of the Oswaldo Cruz Institute. Atas da Sociedade de Biologia do Rio de Janeiro, Rio de Janeiro, 19 (Supl.): 1-29. 
Travassos, L. 1917. Alguns helminthos da collecção do Instituto Bacteriológico de S. Paulo. Brazil-Medico, Rio de Janeiro, 31 (12): 99-100.

Travassos, L. 1918. Informações sobre a família Katlanidae, n.nom. Revista da Sociedade Brasileira de Sciencias, Rio

Received in 21.I.2006; accepted in 25.VIII.2006. de Janeiro, 2: 83-88

Travassos, L. 1922. Contribuições para o conhecimento da fauna helmintolojica brasileira-XVI. Cruzia tentaculata (Rud., 1819). Memórias do Instituto Oswaldo Cruz, Rio de Janeiro, 14 (1): 88-94. 